\title{
A STUDY ON EVALUATION OF POTASSIUM ABNORMALITIES IN A TERTIARY CARE HOSPITAL
}

\section{K. RAWHEENA MAYEE ${ }^{2}$, VIDHYA MAHESHWARAM ${ }^{1}$, SAHITYA KAMJULA ${ }^{1}$, K. SRUJANA $^{1}$, NAVEEN KUMAR VASA ${ }^{1}$, APARNA YERRAMILLI ${ }^{2}$, SANJEEV SHARMA ${ }^{3}$}

${ }^{1}$ Pharm D, Sri Venkateshwara College of Pharmacy, ${ }^{2}$ Department of Pharmacy Practice, Sri Venkateshwara College of Pharmacy,Affiliated Osmania University, Hyderabad, Telangana, India. ${ }^{3}$ Clinical Pharmacologist, Apollo Hospitals, Hyderabad, Telangana, India

Email: rawheena27@gmail.com

Received: 20 Jun 2018 Revised and Accepted: 01 Mar 2019

\begin{abstract}
Objective: To study the occurrence, causes, predisposing factors and management of potassium abnormalities in a tertiary care hospital.
\end{abstract}

Methods: Inour study which was for aduration of six months, we recorded patient demographics, electrolyte levels, complete blood picture, liver function tests, renal parameters, comorbid conditions, medication reconciliation and electro cardio gram (ECG) changes. The data was analyzed to find out the cause for potassium abnormality and was categorize based on their severity.

Results: A total of 200 cases of potassium abnormalities was normalized during the study period. We observed 158(80\%) cases with hypokalemia, $37(17 \%)$ cases with hyperkalemia and $5(3 \%)$ cases with subsequent Potassium abnormalities. We observed the majority of hypokalemiaare with disease induced $87(55.06 \%)$ cases and 118 (74.0\%) cases were with mild hypokalemia. Syrup potassium chloride was used to normalize the serum potassium levels. Majority of the hyperkalemia cases were disease induced and was found in $19(51.35 \%)$ cases and $22(59.45 \%)$ cases come under mild category which was managed with injection calcium gluconate.

Conclusion: Hypokalemia was the most common potassium abnormality seen in hospitalized patients. Disease induced potassium abnormalities was found to be more common in both hypo and hyperkalemia. The potassium levels were normalized with no major negative outcomes. Continuous monitoring of electrolyte levels is required for the patient to prevent further complications.

Keywords: Hypokalemia, Hyperkalemia, Disease induced, Drug-induced, Potassium supplements

(C) 2019 The Authors. Published by Innovare Academic Sciences Pvt Ltd. This is an open access article under the CC BY license (http://creativecommons.org/licenses/by/4.0/) DOI: http://dx.doi.org/10.22159/ijpps.2019v11i4.28033

\section{INTRODUCTION}

In physiology, the primary ions of the electrolytes are sodium $(\mathrm{Na}+)$ potassium $(\mathrm{K}+)$, calcium $(\mathrm{Ca} 2+)$, chloride $\left(\mathrm{Cl}^{-}\right)$, hydrogen phosphate (HPO4 2-), and hydrogen carbonate (HCO3-) [1]. Potassium is one amongst those which is the most abundant cation in the body, with estimated total-body stores of 3,000 to $4,000 \mathrm{mmol}$. About $98 \%$ of potassium is seen within the intracellular compartment, and the remaining $2 \%$ is distributed within the extracellular compartment The Sodium-Potassium adenosine triphosphate $\left(\mathrm{Na}^{+}-\mathrm{K}^{+}\right.$-ATPase $)$ pump located in the cell membrane is responsible for the compartmentalization of Potassium. This pump is an active transport system that maintains increased intracellular stores of Potassium by transporting Sodium out of the cell and Potassium into the cell at a ratio of 3:2. Consequently, the pump maintains a higher concentration of potassium inside the cell. Potassium plays a main role in the transmission of nerve impulse, contraction of muscles and maintenance of fluid balance in the body [2].

The normal value of serum potassium is 3.5-5.0 mmol/l. Hypokalemia is an electrolyte imbalance and is indicated by a low level of Potassium in the blood. Hypokalemia is divided into 3 categories based on serum potassium levels; mild 3.0-3.5 mmol/l, moderate $2.5-3.0 \mathrm{mmol} / \mathrm{l}$ and severe $<2.5 \mathrm{mmol} / \mathrm{l}$. Up to $21 \%$ of hospitalized patients have serum potassium levels lower than $3.5 \mathrm{mmol} / \mathrm{l}$, with $5 \%$ of patients exhibiting potassium levels lower than $3 \mathrm{mmol} / \mathrm{l}$ [3].Hyperkalemia is defined as serum potassium concentration greater than $5.0 \mathrm{mmol} / \mathrm{l}$. It is less common than hypokalemia. Hyperkalemia is divided into 3 categories based on serum electrolytes; mild 5.1-5.5 mmol/l, moderate 5.6-6.0 mmol/l and severe $>6 \mathrm{mmol} / \mathrm{l}$. The incidence of hyperkalemia in hospitalized patients has been estimated to be 1.4$10 \%$ [4].

One of the most common electrolyte complications are Potassium abnormalities in hospitalized patients. Potassium is one of the critical electrolytes involved in various cellular activities. Potassium loss in the body affects the quality of life of the patient and increases morbidity and mortality. So, it is very important to monitor the potassium levels, initiate the standard treatment immediately and normalize them [5]. Hence in this study, we aimed to capture the data regarding the potassium abnormalities in the hospital setting and understand the causes and their management strategies.

\section{MATERIALS AND METHODS}

The present study was a prospective and observational study conducted at Apollo Hospitals, Jubilee Hills, Hyderabad, India. This study was approved by the institutional ethical committee (No: SVCP/2015/28) Case records of the inpatients who are above or equal to $18 \mathrm{y}$ with abnormal potassium values were included and outpatients are excluded from the study. The data was collected regarding patient's demographics such as age, family history, co-morbid conditions, abnormal potassium values, dose, frequency, lab parameters such as serum electrolytes values (Sodium, Calcium, Magnesium and Chlorides), Serum Creatinine (S. Cr), complete blood picture, electro cardiogram (ECG), liver function tests like albumin, globulin, and alkaline phosphatase were recorded. Statistical analysis is done by using descriptive statistics and CI of mean. Descriptive analysis was used to report the findings of continuous data and Categorical data, potassium abnormalities was analyzed by confidence intervals of their respective means.

\section{RESULTSAND DISCUSSION}

A total of 200 in-patients who have abnormal potassium values were considered for the study, of which the majority were males $(53 \%)$. Higher percentage of our study population belonged to the age group of 51-60 y (27\%), as it is known that risk of cardiovascular disease (Hypertension, Coronary artery diseases) and renal disease (Chronic kidney disease and Acute kidney injury) are significantly higher in this age(table 1). Blood pressure increases with age and lifetime risk of developing cardiovascular diseases among those of 55 y age and older was observed to be $90 \%[6,7]$.

Majority of our study population were found to be overweight and obese with an average body mass index (BMI) of $27.4 \mathrm{~kg} / \mathrm{m}^{2}$.Obesity is 
characterized by a marked insulin resistance which involves an abnormal regulation of Potassium uptake and metabolism (table 1).

The disease induced hypokalemia 87 (55.06\%) cases and hyperkalemia $19(51.35 \%)$ cases, and the drug-induced hypokalemia 71 (44.93\%) cases and hyperkalemia 18 (48.65\%) cases, were observed among 158 cases of hypokalemia (The 95\% confidence interval extends from 0.7281 to 0.8410 ) and37 cases of hyperkalemia (The 95\% confidence interval extends from 0.1370 to 0.2449 ) respectively (table 2).

Chronic kidney disease (CKD), diabetes mellitus (DM), hypertension (HTN), coronary artery disease (CAD) and urinary tract infections (UTI) are the conditions where potassium abnormalities were seen to a larger extent. In our study we noted that Lactulose, furosemide, methylprednisone, noradrenaline, actrapid, perindopril, enalapril, irbesartan, telmisartan, aspirin, and combinational drugs like furosemide +lactulose, non-steroidal anti-inflammatory drugs and angiotensin-converting enzyme inhibitors (NSAIDS+ACEI), $\beta$ blockers, angiotensin receptor blockers and beta blockers(ARB $+\beta$ blockers)are the drugs causing potassium abnormalities (table 3 ). Among disease induced hypokalemia, nephrotic disorders are the prime reasons, it can be because of increased water intake and increased reabsorption of sodium chloride and water offer to sustain the edemas, while aldosterone promotes renal excretion of $\mathrm{K}+$ and $\mathrm{H}+$ leads to develop hypokalemia and alkalosis $[8,9]$.

Table 1: Patient demographics $(\mathrm{N}=200)$

\begin{tabular}{ll}
\hline Gender & No of cases (\%) \\
\hline Females & $94(47 \%)$ \\
Males & $106(53 \%)$ \\
Age & No of cases $(\%)$ \\
Years & $19(9.5 \%)$ \\
$18-30$ & $27(13.5 \%)$ \\
$31-40$ & $27(13.5 \%)$ \\
$41-50$ & $54(27 \%)$ \\
$51-60$ & $45(22.5 \%)$ \\
$61-70$ & $28(14 \%)$ \\
$>71$ & \\
BMI & No of cases $(\%)$ \\
BMI (kg/m ${ }^{2}$ ) Range & $40(20 \%)$ \\
Underweight $<18$ & $46(23 \%)$ \\
Normal $18.5-24.9$ & $70(35 \%)$ \\
Overweight $25-29.9$ & $34(17 \%)$ \\
Obese $30-39.9$ & $10(5 \%)$ \\
Morbid obese $>40$ & \\
\hline
\end{tabular}

Table 2: Details of Potassium abnormalities in the study population $(\mathrm{N}=200)$

\begin{tabular}{llll}
\hline Potassium abnormality & Hypokalemia & Hyperkalemia & Subsequent K+ abnormality \\
\hline $\begin{array}{l}\text { Serum K }{ }^{+} \text {value }<3.5 \mathrm{mmol} / \mathrm{l} \\
>5.0 \mathrm{mmol} / \mathrm{l}\end{array}$ & $158^{*}(80 \%)$ & - & $05(3 \%)$ \\
Severity & - & $37^{* *}(17 \%)$ & - \\
Mild & $118(74.6 \%)$ & $22(59.45 \%)$ & $03(60 \%)$ \\
Moderate & $35(22.15 \%)$ & $10(27.02 \%)$ & 0 \\
Severe & $05(3.16 \%)$ & $05(13.51 \%)$ & $02(40 \%)$ \\
Etiology & Hypokalemia & Hyperkalemia & Subsequent potassium abnormality \\
Categories & $87(55.06 \%)$ & $19(51.35 \%)$ & $05(100 \%)$ \\
$\begin{array}{l}\text { Disease induced } \\
\text { Drug induced }\end{array}$ & $71(44.93 \%)$ & $18(48.65 \%)$ & - \\
ECG Changes (n= 17) & & & Disease induced \\
Sinus Tachycardia & Drug-induced & & $4(29 \%)$ \\
Hypokalemia & $10(71 \%)$ & & $2(66.7 \%)$ \\
Hyperkalemia & $1(33.3 \%)$ & & \\
\hline
\end{tabular}

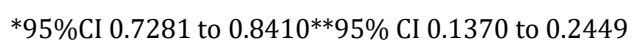

Table 3: Common drugs in dosing potassium abnormalities $(\mathrm{N}=200)$

\begin{tabular}{lll}
\hline \multicolumn{2}{l}{ Drugs causing potassium abnormalities } & No of cases (\%) \\
\hline Class & Drug & $19(26.76 \%)$ \\
\hline Hypokalemia (n= 158) & & $13(18.30 \%)$ \\
Laxatives & Lactulose & $06(8.45 \%)$ \\
Loop diuretics & Furosemide & $01(1.40 \%)$ \\
Corticosteroids & Methyl prednisone & $01(1.40 \%)$ \\
Catecholamine & Nor adrenaline & $09(12.67 \%)$ \\
Insulin & Actrapid & $02(11.11 \%)$ \\
Combination & Furosemide +Lactulose & \\
Hyperkalemia (n=37) & & $02(11.11 \%)$ \\
ACEI's* & Perindopril & $01(5.55 \%)$ \\
& Enalapril & $01(5.55 \%)$ \\
ARB'S* & Irbesartan & $02(11.11 \%)$ \\
NSAIDS* & Telmisartan & $02(11.11 \%)$ \\
Combinations & Aspirin & $02(11.11 \%)$ \\
& NSAIDS+ACEI'S, & $02(11.11 \%)$ \\
\hline
\end{tabular}

ACEI's: Angiotensin Converting Enzyme Inhibitors, ARB's: Angiotensin Receptor Blockers, NSAIDS: Non-Steroidal Anti-Inflammatory Drugs 


\section{Management of Hypokalemia and Hyperkalemia:}

The Serum Potassium levels in hypokalemia patients were normalized with $10 \mathrm{ml}(13.3 \mathrm{mEq})$ of Potassium chloride syrup, which was administered three times a day in 27 (17\%) cases, which showed $0.5 \mathrm{mmol} / \mathrm{l}$ increase in Serum Potassium. Injection potassium chloride $(\mathrm{KCl})$ was given in $28(17.7 \%)$ cases and were managed with $40 \mathrm{mEq}$ given twice a day, which showed an increase of $0.3 \mathrm{mmol} / \mathrm{l}$ serum potassium(table 4 ).

Potassium citrate and magnesium citrate (Potrate M) was also given for the management of hypokalemia when there was an abnormality of magnesium in metabolic alkalosis patients. Potrate $\mathrm{M}$ was given in $4(2.5 \%)$ cases with $15 \mathrm{ml}$ twice a day, showed an increase of $0.5 \mathrm{mmol} / \mathrm{l}$ serum potassium. In our study, combination therapy was given for the management of hypokalemia. Syrup potassium chloride (Potrate) $20 \mathrm{ml}$ and injection Potassium chloride $10 \mathrm{mEq}$, stat was given in $8(5 \%)$ cases, which showed an increase of $0.4 \mathrm{mmol} / \mathrm{l}$ (table 4 ).

For the management of hyperkalemia, parenteral, nebulizers and oral dosage forms were prescribed. Calcium gluconate, insulin, potassium bind was given as injections and as nebulizers salbutamol +ipratropium Bromide, Salbutamol were given and as oral dosage form furosemide, Potassium bind sachet, Sodium bicarbonate were given. Out of all these drugs in our studyinj. Calcium gluconate, $10 \mathrm{ml}$ stat was found to decrease serum potassium by $0.2 \mathrm{mmol} / \mathrm{l}$ in $3(8.1 \%)$ cases and Potassium bind sachet $15 \mathrm{ml}$ per oral once a day, salbutamol+ ipratropium Bromide2cc nebulizer four times a day and Salbutamol $1 \mathrm{cc}$ nebulizer three times a day were given in2 (5.4\%), 2(5.4\%), 1(2.7\%) cases respectively which showed decrease of $0.1 \mathrm{mmol} / \mathrm{l}$ serum potassium in all the three. Sodium bicarbonate $500 \mathrm{mg}$ per oral twice daily was given in $2(5.4 \%)$ cases which showed a decrease of 1.1 mmol/l of serum Potassium.Furosemide $20 \mathrm{mg}$ per oral twice daily and subcutaneous Insulin 16 units once a day was given in $1(2.7 \%)$ case which showed decrease of $0.2 \mathrm{mmol} / \mathrm{l}$ serum potassium respectively(table 4).

Hyperkalemia was also managed using more than one drug. In our study the combination drugs were inj. Calcium gluconate $10 \mathrm{ml}$ stat and Salbutamol 2cc nebulizer three times a day was given in 2 (5.4\%) cases Which Showed a decrease of $0.3 \mathrm{mmol} / \mathrm{l}$ of serum potassium(table 4 ).

Table 4: Management of potassium abnormalities in the study population $(\mathrm{N}=200)$

\begin{tabular}{|c|c|c|c|c|c|c|}
\hline \multicolumn{7}{|l|}{ Hypokalemia $(n=158)$} \\
\hline \multirow{2}{*}{$\begin{array}{l}\text { Drug } \\
\text { Syrup }\end{array}$} & \multirow{2}{*}{$\begin{array}{l}\text { Dose } \\
10 \mathrm{ml}\end{array}$} & \multirow{2}{*}{$\begin{array}{l}\begin{array}{l}\text { No of } \\
\text { cases }\end{array} \\
41\end{array}$} & \multirow{2}{*}{$\begin{array}{l}\text { Route } \\
\text { PO }\end{array}$} & \multicolumn{2}{|c|}{ Frequency } & \multirow{2}{*}{$\begin{array}{l}\begin{array}{l}\text { Average increase in } \\
\mathrm{K}+\text { value (mmol) }\end{array} \\
0.1\end{array}$} \\
\hline & & & & OD & 01 & \\
\hline \multirow[t]{3}{*}{ Potassium chloride } & & & & BD & 12 & 0.3 \\
\hline & & & & TID & 27 & 0.5 \\
\hline & & & & QID & 01 & 0.7 \\
\hline Inj. Potassium chloride & $40 \mathrm{meq}$ & 28 & IV & $\mathrm{BD}$ & 28 & 0.3 \\
\hline \multirow[t]{2}{*}{ Potassium citrate and Magnesium citrate, } & $15 \mathrm{ml}$ & 07 & PO & BD & 04 & 0.5 \\
\hline & & & & TID & 03 & 0.8 \\
\hline Potassium citrate and Magnesium citrate & $20 \mathrm{ml}$ & 08 & PO & Stat & & 0.4 \\
\hline+ & $10 \mathrm{meq}$ & & IV & & & \\
\hline \multicolumn{7}{|l|}{ Inj. Potassium chloride } \\
\hline \multicolumn{7}{|l|}{ Hyperkalemia $(n=37)$} \\
\hline Drug & Dose & $\begin{array}{l}\text { No of } \\
\text { cases }\end{array}$ & Route & Freq & & $\begin{array}{l}\text { Average decrease in } \\
\text { K+value (mmol) }\end{array}$ \\
\hline Calcium gluconate & $10 \mathrm{ml}$ & 03 & IV & Stat & & 0.2 \\
\hline Furosemide & $20 \mathrm{mg}$ & 01 & PO & $\mathrm{BD}$ & & 0.2 \\
\hline Potassium Bind Sachet & $15 \mathrm{ml}$ & 02 & PO & OD & & 0.1 \\
\hline Salbutamol +Ipratropium Bromide & $2 \mathrm{cc}$ & 02 & $\mathrm{Neb}$ & QID & & 0.1 \\
\hline Salbutamol & $1 \mathrm{cc}$ & 01 & $\mathrm{Neb}$ & QID & & 0.1 \\
\hline Sodium bicarbonate & $500 \mathrm{mg}$ & 02 & PO & $\mathrm{BD}$ & & 1.1 \\
\hline Insulin & $16 \mathrm{U}$ & 01 & SC & HS & & 0.2 \\
\hline Calcium gluconate+ & $10 \mathrm{ml}$ & 02 & IV & Stat & & 0.3 \\
\hline Salbutamol & $2 \mathrm{cc}$ & & $\mathrm{Neb}$ & TID & & \\
\hline
\end{tabular}

In a few cases extra supplementation of potassium led to hyperkalemia and upon treatment, it subsequently resulted in hypokalemia. Such kind of Potassium abnormalities was found to be $5(3 \%)$ cases in our study. In subsequent hypokalemia and hyperkalemia, mild and severe cases were seen in 3 and 2 cases respectively, which are found in both disease and drug induced Potassium abnormalities (table 2).
Patients with longer duration of hospital stay were observed to be with subsequent hypokalemia and hyperkalemia as these patients require continuous monitoring. The initiation of potassium supplements was influenced by the duration of stay in these patients. Naranjo's causality scale was used to assess the causality of potassium abnormalities. In our study, we found that about half of the cases of druginduced hypokalemia and the drug-induced hyperkalemia were possible (table 5).

Table 5: Causality assessment

\begin{tabular}{lll}
\hline Naranjo's scale (n=89) & Hypokalemia (71) & Hyperkalemia (18) \\
\hline Probable (5-8) & 25 & 06 \\
Possible(1-4) & 30 & 09 \\
Definite( $\geq 9)$ & 14 & 03 \\
Doubtful & 02 & 00 \\
\hline
\end{tabular}

\section{LIMITATIONS}

Difficulty in accessing data in ICU and Hemodialysis department. Since, data collected was from inpatient only, the status of improvement in potassium levels after discharge was unavailable.

\section{CONCLUSION}

From our study, we observed that hypokalemia was the most common potassium abnormality. The common causes of the abnormalities were because of diseases. However, they were mild in 
nature and were treated with no negative outcome. Regular monitoring is required to prevent further complications and to improve the quality of life.

\section{ACKNOWLEDGMENT}

It is a pleasant task to express our thanks to all those who contributed in many ways to the success of this study. We are thankful to the Principal Dr. M. Bhagavan Raju and Management of Sri Venkateshwara College of Pharmacy, Apollo Hospitals, Jubileehills for their support in carrying out this project. Funding: None.

\section{AUTHORS CONTRIBUTIONS}

Vidya Maheshwaram, Sahitya K, Srujana K and Naveen Kumar V, Pharm D students collected the data. Dr Rawheena Mayee research guide, Dr Aparna Yerramilli, Dr Sanjeev sharmaco-guides of this study contributed in the designof the study, protocol process, data analysis and manuscript writing.

\section{CONFLICT OF INTERESTS}

The author(s) declare(s) that they have no conflicts of interest to disclose.

\section{REFERENCES}

1. Olubunmi CO jo, Modupe F Asaolu. Status of plasma electrolytes, urea, creatinine, andc-reactive protein in cancer patients. Asian J Pharm Clin Res2018;11:268-70.
2. Lawrence J Appel, David H, Baker Potassium. Dietary reference intakes for water, potassium, sodium, chloride, and sulfate. Washington, dc: the national academies Press; 2005. p. 186-268.

3. RobertJ luft, Friedrich C Shirley. Pathophysiology and management of hypokalemia: a clinical perspective. National Rev Nephrol 2011;10:2010-75.

4. Marjorie JArca, Brian Kenney. The management of hyperkalemia in the emergency department.J Accident Emergency Med2010;17:181-92.

5. Cohn JN, Kowey PR, Whelton PK, Prisant LM. New guidelines for potassium replacement in clinical practice a contemporary review by the national council on potassium in clinical practice. Arch Intern Med2000;160:2429-36.

6. Matsui H, Shimosawa T, Uetake Y, Wang H, Ogura S, Kaneko T, et al. Protective effect of potassium against the hypertensive cardiac dysfunction: association with reactive oxygen species reduction. Hypertension2006;48:225-31.

7. Krauss RM, Eckel RH, Howard B, Appel LJ, Daniels SR, Deckelbaum RJ, et al. AHA dietary guidelines. Revision 2000:a statement for healthcare professionals from the Nutrition Committee of the American Heart Association. Stroke 2000;31:2751-66.

8. David B Mount. Fluid and electrolyte disturbances. In: Jameson Fauci, Braunwald, Kasper. editors. Harrison's principles of internal medicine.20 $0^{\text {th }}$ ed.New York: McGraw-Hill, Medical Pub. Division; 2005;46:281-96.

9. Harikesh Maurya. Tirath Kumar. A review on comprehensive overview in the management of nephrotic disorders. J Critical Rev 2016;3:34-43. 